\title{
Plasma cardiac natriuretic peptide determination as a screening test for the detection of patients with mild left ventricular impairment
}

\author{
Torbjørn Omland, Asbjørn Aakvaag, Harald Vik-Mo
}

\begin{abstract}
Objective-To determine the usefulness of measuring the cardiac natriuretic peptides, atrial natriuretic factor, $\mathbf{N}$-terminal pro-atrial natriuretic factor, and brain natriuretic peptide, as screening tests for identifying patients with mild left ventricular impairment.
\end{abstract}

Design-Cross-sectional evaluation of the diagnostic accuracy of the cardiac natriuretic peptides.

Setting-Cardiac catheterisation unit, Norwegian central hospital.

Patients-A consecutive series of 254 patients undergoing diagnostic left-sided cardiac catheterisation. One hundred and twenty eight of these patients had a history of previous myocardial infarction.

Main outcome measures-The presence of normal and impaired left ventricular function, as evaluated by logistic regression analysis and estimation of the area under the receiver operating characteristic (ROC) curve (an index of overall diagnostic accuracy). Ventricular function was assessed by the measurement of left ventricular end diastolic pressure and angiographically determined left ventricular ejection fraction.

Results-Logistic regression analysis showed that plasma brain natriuretic peptide was the best predictor of increased left ventricular end diastolic pressure ( $\geqslant 15 \mathrm{~mm} \mathrm{Hg})(P<0.001)$, decreased left ventricular ejection fraction $(\leqslant 45 \%)(P<$ $0 \cdot 001$ ), and the combination of left ventricular ejection fraction $\leqslant 45 \%$ and left ventricular end diastolic pressure $\geqslant 15$ mm $\mathrm{Hg}(\mathrm{P}<0.001)$. The areas under the ROC function for the detection of left ventricular dysfunction were 0.789 for brain natriuretic peptide, 0.665 for atrial natriuretic factor, and 0.610 for $\mathrm{N}$-terminal pro-atrial natriuretic factor.

Conclusions-Plasma brain natriuretic peptide seemed to be a better indicator of left ventricular function than plasma atrial natriuretic factor or $\mathbf{N}$-terminal pro-atrial natriuretic factor. However, the overall diagnostic accuracy of circulating atrial natriuretic factor, $\mathbf{N}$-terminal proatrial natriuretic factor, and brain natriuretic peptide as indicators of normal and impaired ventricular function in an unselected group of patients with coronary heart disease and a high frequency of previous myocardial infarction was relatively modest.
(Heart 1996;76:232-237)

Keywords: chronic heart failure; left ventricular function; brain natriuretic peptide; N-terminal pro-atrial natriuretic factor

Clinical trials during the past few years have clearly shown that angiotensin converting enzyme inhibitors significantly reduce mortality and morbidity in patients with myocardial infarction and objective or clinical signs of left ventricular dysfunction ${ }^{12}$ as well as in patients with chronic asymptomatic or symptomatic left ventricular dysfunction, ${ }^{34}$ suggesting that patients with mild or asymptomatic heart failure may benefit from early pharmaceutical intervention. The prevalence of asymptomatic left ventricular dysfunction, as assessed by echocardiography in a population-based study, has recently been reported to be about $3 \%, 5$ indicating that this condition is a public health problem of major importance. Regrettably, clinical assessment is not a very reliable method in the diagnosis of heart failure and ventricular dysfunction. ${ }^{6}$ The cost of referring all patients with possible mild heart failure for objective assessment of left ventricular function is high and probably exceeds the capacity of most hospitals in terms of equipment and availability of skilled personnel.

Circulating concentrations of the cardiac natriuretic peptide family, atrial natriuretic factor, ${ }^{7-9}$ the $\mathrm{N}$-terminal fragment of pro-atrial natriuretic factor, ${ }^{10}$ and brain natriuretic peptide $^{1112}$ are all higher in left ventricular dysfunction and in chronic heart failure. Significant correlations between plasma concentrations of these peptides and indices of cardiac function have been documented. ${ }^{13-17} \mathrm{It}$ has therefore been suggested that circulating natriuretic peptides may be used as markers of asymptomatic left ventricular dysfunction in patients with suspected or known cardiac disease, ${ }^{1018}$ and even be used as a criterion for treatment with angiotensin converting enzyme inhibitors in patients with mild heart failure. ${ }^{19}$ Recent data also indicate that enhanced in vitro stability of $\mathrm{N}$-terminal pro-atrial natriuretic factor and brain natriuretic peptide permits less rigorous handling of blood samples compared to what is required for other peptide hormones, ${ }^{2021}$ making $\mathrm{N}$-terminal pro-atrial natriuretic factor and brain natriuretic peptide ideal candidates for the purpose of detecting mild left ventricular impairment in cases where complex laboratory facilities are not available. 
The major objective of the present prospective study was to evaluate the diagnostic value of circulating natriuretic peptides as indicators of cardiac function in a relevant target population. Because ischaemic heart disease is currently the most common cause of left ventricular dysfunction, ${ }^{34}$ a large, consecutive series of patients undergoing diagnostic cardiac catheterisation was enrolled in the study, based on the rationale that this population would encompass a large proportion of patients with previous myocardial infarction and varying degree of left ventricular dysfunction.

\section{Patients and methods PATIENTS}

Patients undergoing diagnostic cardiac catheterisation for suspected coronary heart disease during a six month recruitment period were eligible for this study. Patients with a recent myocardial infarction $(<2$ weeks), significant valvar heart disease, significant cardiac arrhythmia (including atrial fibrillation), ongoing cardiac ischaemia as evidenced by ST-T segment depression, and manifest renal or hepatic failure were ineligible because these conditions are known to influence significantly plasma concentrations of the natriuretic peptides. Patients with severe symptomatic chronic heart failure (New York Heart Association class III or IV) were ineligible, because these patients rarely represent a diagnostic problem and because the objective of the study was to identify patients with mild or asymptomatic cardiac impairment. Patients were enrolled consecutively during the time the primary investigator (TO) was working in the catheterisation laboratory. Before catheterisation was performed all patients had been interviewed and examined by two experienced physicians following a standardised procedure that included assessment of New York Heart Association functional class.

A total of 263 patients with suspected coronary heart disease were originally included in the study. Nine patients were excluded owing to the following causes: cardiac arrhythmia during the investigation (three patients), pronounced vasovagal reaction requiring leg elevation during the investigation (one patient), discovery of undiagnosed mitral valve prolapse (one patient), recent undiagnosed myocardial infarction (one patient) and technical errors in handling of blood samples (three patients), leaving 254 patients for data analysis. All patients gave informed, written consent to participate in the study. Approval of the study protocol had been obtained from the Regional Ethics Committee, Health Region III, Bergen, Norway, before the start of the study.

Left ventricular end diastolic pressure and left ventricular ejection fraction were prospectively defined as the two major outcome variables describing cardiac function. The predefined cutoff points were $15 \mathrm{~mm} \mathrm{Hg}$ for left ventricular end diastolic pressure and $45 \%$ for left ventricular ejection fraction. In addition, the ability of the natriuretic peptides to identify patients with (a) left ventricular dysfunction (ejection fraction $\leqslant 45 \%$ and end diastolic pressure $\geqslant 15 \mathrm{~mm} \mathrm{Hg}$ ) and (b) with normal left ventricular function (ejection fraction $\geqslant 55 \%$, end diastolic pressure $<15 \mathrm{~mm}$ $\mathrm{Hg}$, and no angiographic sign left ventricular hypokinesis) was investigated.

\section{STUDY PROCEDURE}

After at least 15 minutes' supine rest, the femoral artery and vein were cannulated and a pigtail catheter introduced into the aorta. Before contrast ventriculography, a $10 \mathrm{ml}$ blood sample was drawn from the descending aorta into a prechilled plastic tube containing EDTA and aprotinin. The test tube was immediately placed on ice and centrifuged at $4^{\circ} \mathrm{C}$ within 15 minutes of blood collection. After blood sampling, the catheter was first placed in the ascending aorta for the registration of aortic blood pressure curves, then introduced retrogradely into the left ventricle through the aortic valve for registration of intraventricular blood pressure curves. Left ventricular end diastolic pressure was defined as a trough in the pressure pulse following the atrial contraction wave, immediately preceding the upstroke of left ventricular pressure. Left ventricular ejection fraction was ascertained by single plane contrast ventriculography in the $30^{\circ}$ right oblique projection during held inspiration, using the area-length method. ${ }^{22}$ Haemodynamic measurements were performed by one investigator (HVM), who was blinded to the hormone data.

The plasma samples were stored at $-70^{\circ} \mathrm{C}$ until analysis. Atrial natriuretic factor in plasma was determined by radioimmunoassay using kits from Amersham International (UK) after previous extraction on a C18 octadecyl silica microcolumn (Milipore). The procedure and the performance characteristics of this assay in our laboratory have been reported in detail elsewhere. ${ }^{23}$ The analysis of $\mathrm{N}$-terminal pro-atrial natriuretic factor was performed by direct radioimmunoassay without prior extraction of peptide. ${ }^{24}$ The antibody was directed at the amino-acid sequence $79-98$. No cross reactivity with atrial natriuretic factor was observed. The sensitivity of the assay was 40 $\mathrm{pmol} / \mathrm{l}$ and the coefficients of variation within assay and between assay were $<10 \%$ and $<15 \%$, respectively. Brain natriuretic peptide in plasma was analysed using radioimmunoassay after prior extraction with Vycor glass (Crown Corning, Liverpool, NSW, Australia). The mean recovery rate was $71 \%$. The minimum detectable concentration was 0.45 $\mathrm{fmol} /$ tube. Within assay and between assay coefficients of variation were $7 \%$ and $10 \%$, respectively. The analytical procedure has been described in detail elsewhere. ${ }^{25}$ Creatinine, sodium, and potassium concentrations in serum were determined by routine laboratory methods.

\section{STATISTICAL ANALYSIS}

Haemodynamic and hormonal data are expressed as mean (SD). However, owing to a skewed distribution of hormonal data, loga- 
Table 1 Characteristics of patients

\begin{tabular}{lc}
\hline Variable & Value \\
\hline Demographics: & \\
Mean age (yr) & $59(10)$ \\
Male sex (\%) & $76 \cdot 0$ \\
Medical history: & $50 \cdot 4$ \\
Previous myocardial infarction (\%) & $95 \cdot 7$ \\
Previous angina pectoris (\%) & $14 \cdot 6$ \\
Coronary artery bypass grafting (\%) & \\
Percutaneous transluminal & $16 \cdot 9$ \\
percutaneous angioplasty (\%) & $32 \cdot 7$ \\
Hypertension (\%) & $4 \cdot 7$ \\
Diabetes mellitus (\%) & $5 \cdot 1$ \\
Chronic heart failure (\%) & $75 \cdot 2$ \\
Drug treatment: & $73 \cdot 6$ \\
Aspirin (\%) & $33 \cdot 5$ \\
$\beta$ Blockers (\%) & $52 \cdot 4$ \\
Calcium channel blockers (\%) & $13 \cdot 0$ \\
Peroral nitrates (\%) & $9 \cdot 4$ \\
Converting enzyme inhibitors (\%) & $10 \cdot 2$ \\
Cholesterol-lowering drugs (\%) & \\
Diuretics (\%) & $47 \cdot 2$ \\
Catheterisation data: & $15 \cdot 4$ \\
Left ventricular hypokinesia (\%) & $22 \cdot 0$ \\
Angiographically normal coronary arteries (\%) \\
Single vessel disease (\%) & $25 \cdot 2$ \\
Double vessel disease (\%) & $37 \cdot 8$ \\
Triple vessel disease (\%) & $15 \cdot 3(5 \cdot 6)$ \\
Left ventricular end diastolic pressure (mm Hg) & $64 \cdot 5(11 \cdot 9)$ \\
Left ventricular ejection fraction (\%) & \\
\hline &
\end{tabular}
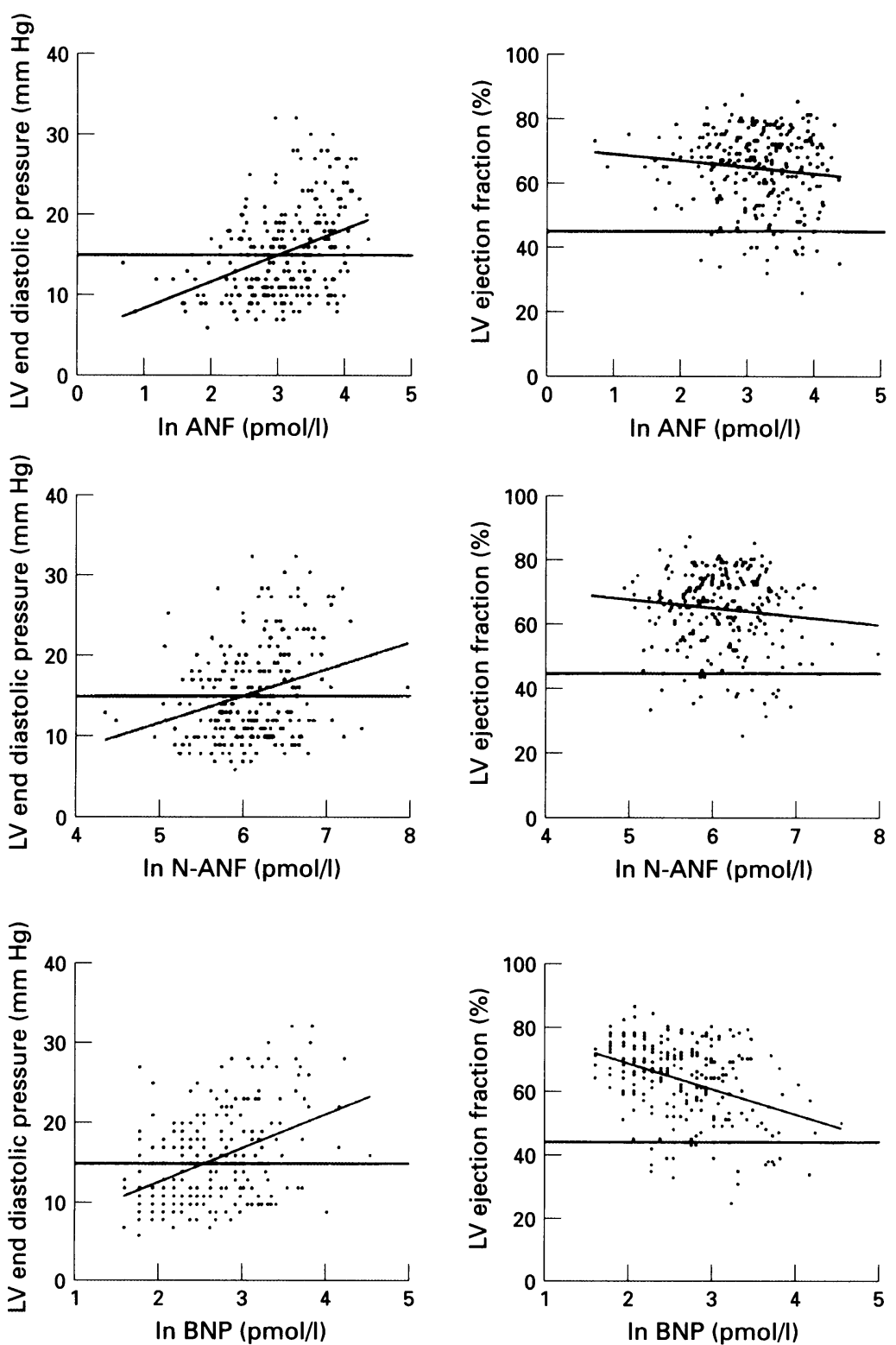

Figure 1 Relation between plasma concentrations of atrial natriuretic factor $(A N F), N-$ terminal pro-atrial natriuretic factor (N-ANF), and brain natriuretic peptide (BNP) and left ventricular end diastolic pressure (LVEDP) and left ventricular ejection fraction (LVEF). Horizontal lines indicate predefined decision thresholds (LVEDP $15 \mathrm{~mm} \mathrm{Hg}$; LVEF 45\%). rithmic transformation of these values was performed. Pearson correlation and linear regression analysis were employed to assess the relation between the hormonal and haemodynamic variables. Logistic regression analysis was used to assess the ability of atrial natriuretic factor, N-terminal pro-atrial natriuretic factor, and brain natriuretic peptide to identify the prespecified subgroups of patients. Receiver operating characteristic (ROC) plots were generated to visualise the sensitivity and specificity through the complete range of plasma concentrations of the natriuretic peptides, using the software programme ROCLAB. ${ }^{26}$ This computer program was also used to estimate the area under the ROC curve, which represents an index of overall test accuracy. ${ }^{27}$ By convention this area ranges from 0.5 to 1.0 , with a value of 0.5 meaning no apparent distributional difference between the two dichotomous classes and an area value of 1.0 meaning no distributional overlap (that is, perfect separation). So-called enhanced estimates of the area under the ROC function are reported.

\section{Results}

The demographic, clinical, and angiographic characteristics of the patients are presented in table 1. Plasma atrial natriuretic factor averaged $26 \cdot 7(15 \cdot 2) \mathrm{pmol} / \mathrm{l}$, plasma $\mathrm{N}$-terminal pro-atrial natriuretic factor averaged 518 (297) $\mathrm{pmol} / \mathrm{l}$, and plasma brain natriuretic peptide averaged 16.7 (12.0) pmol/1. Figure 1 shows the relation between plasma concentrations of the cardiac natriuretic peptides and left ventricular end diastolic pressure and left ventricular ejection fraction. Logarithmically transformed plasma brain natriuretic peptide concentrations correlated significantly with both end diastolic pressure and ejection fraction, whereas logarithmically transformed plasma concentrations of atrial natriuretic factor and $\mathrm{N}$-terminal pro-atrial natriuretic factor correlated significantly with end diastolic pressure but not with ejection fraction. However, the association between the natriuretic peptides and haemodynamic variables was not strong, and less than $25 \%$ of the variability in natriuretic peptide concentrations could be accounted for by the variability in ejection fraction or end diastolic pressure (table 2).

As shown in tables 3 and 4, all three peptides were predictive of left ventricular end diastolic pressure $\geqslant 15 \mathrm{~mm} \mathrm{Hg}$, whereas only brain natriuretic peptide was a significant predictor of left ventricular ejection fraction $\leqslant 45 \%$. Log transformed atrial natriuretic factor and brain natriuretic peptide, but not $\mathrm{N}$ terminal pro-atrial natriuretic factor, concentrations identified patients with left ventricular dysfunction, defined as end diastolic pressure $\geqslant 15 \mathrm{~mm} \mathrm{Hg}$ and ejection fraction $\leqslant 45 \%$ in univariate analysis (table 3 ). Adjustment for patient age in a multivariate model improved somewhat the ability of the natriuretic peptides to identify these subgroups (table 4). 
Table 2 Correlation between circulating cardiac natriuretic peptides (log transformed) and selected variables $(n=254)$

\begin{tabular}{|c|c|c|c|c|c|c|}
\hline & $\ln N-A N F$ & $\ln B N P$ & $L V E D P$ & $L V E F$ & Age & Creatinine \\
\hline In ANF & $0 \cdot 76^{\star \star}$ & $0.63^{\star \star}$ & $0 \cdot 38^{\star \star}$ & -0.11 (NS) & $0.41^{\star \star}$ & 0.12 (NS) \\
\hline $\ln$ N-ANF & - & $0 \cdot 72^{\star \star}$ & $0 \cdot 30^{\star \star}$ & -0.12 (NS) & $0.51^{\star \star}$ & $0 \cdot 19^{\star}$ \\
\hline $\ln \mathrm{BNP}$ & - & - & $0 \cdot 43^{\star \star}$ & $-0.39 \star \star$ & $0.45^{\star \star}$ & 0.12 (NS) \\
\hline LVEDP & - & - & - & $-0.23^{\star \star}$ & $0 \cdot 12$ (NS) & 0.06 (NS) \\
\hline LVEF & - & - & - & - & -0.01 & 0.003 (NS) \\
\hline Age & - & - & - & - & - & $0 \cdot 13^{\star}$ \\
\hline
\end{tabular}

$\star \mathrm{P}<0.05 ;{ }^{\star \star} \mathrm{P}<0.001$.

ANF, atrial natriuretic factor; BNP, brain natriuretic peptide; N-ANF, N-terminal pro-atrial natriuretic factor; LVEDP, left ventricular end diastolic pressure; LVEF, left ventricular ejection fraction; In, natural logarithm.

Table 3 Identification of patient subgroups by cardiac natriuretic peptide determination as assessed by univariate logistic regression analysis

\begin{tabular}{|c|c|c|c|c|}
\hline Natriuretic peptide & Coefficient & $S E$ & Wald $\chi^{2}$ & $P$ \\
\hline $\begin{array}{l}\ln \text { ANF } \\
\ln \text { N-ANF } \\
\ln \text { BNP }\end{array}$ & \multicolumn{4}{|c|}{$\begin{array}{cccc}\text { Patients with LVEF } \leqslant & 45 \% \text { and } L V E D P & \geqslant 15 \mathrm{~mm} \mathrm{Hg}(n=17) \\
-1.067 & 0.484 & 4.86 & 0.028 \\
-0.748 & 0.496 & 2.28 & 0.131 \\
-1.709 & 0.440 & 15.08 & <0.001\end{array}$} \\
\hline $\begin{array}{l}\ln \text { ANF } \\
\ln \text { N-ANF } \\
\ln \text { BNP }\end{array}$ & $\begin{array}{l}\text { Patients } v \\
-1 \cdot 110 \\
-0.888 \\
-1 \cdot 285\end{array}$ & $\begin{array}{l}V E D P \\
0 \cdot 231 \\
0 \cdot 266 \\
0 \cdot 256\end{array}$ & $\begin{array}{l}\operatorname{Hg}(n=13 \\
23 \cdot 18 \\
11 \cdot 18 \\
25 \cdot 16\end{array}$ & $\begin{array}{l}<0.001 \\
<0.001 \\
<0.001\end{array}$ \\
\hline $\begin{array}{l}\ln \text { ANF } \\
\ln \text { N-ANF } \\
\ln \text { BNP }\end{array}$ & $\begin{array}{l}\text { Patie } \\
-0.793 \\
-0.637 \\
-1.382\end{array}$ & $\begin{array}{l}\text { th } L V E F \\
0 \cdot 414 \\
0 \cdot 450 \\
0 \cdot 388\end{array}$ & $\begin{array}{c}(n=21) \\
3 \cdot 66 \\
2 \cdot 00 \\
12 \cdot 69\end{array}$ & $\begin{array}{r}0.056 \\
0.157 \\
<0.001\end{array}$ \\
\hline $\begin{array}{l}\ln \text { ANF } \\
\ln \text { N-ANF } \\
\ln \text { BNP }\end{array}$ & $\begin{array}{l}\text { Patients with } \\
\text { and no angic } \\
0.763 \\
0.808 \\
1.961\end{array}$ & $\begin{array}{l}D P<15 \\
\text { iic sign of } \\
0 \cdot 217 \\
0 \cdot 278 \\
0 \cdot 331\end{array}$ & $\begin{array}{l}L V E F \geqslant \\
\text { kinesis }(n \\
12 \cdot 40 \\
8 \cdot 45 \\
35 \cdot 08\end{array}$ & $\begin{array}{r} \\
<0.001 \\
0.004 \\
<0.001\end{array}$ \\
\hline
\end{tabular}

ANF, atrial natriuretic factor; BNP, brain natriuretic peptide; N-ANF, N-terminal pro-atrial natriuretic factor; LVEDP, left ventricular end diastolic pressure; LVEF, left ventricular ejection fraction.

Table 4 Identification of patient subgroups by cardiac natriuretic peptide determination as assessed by logistic regression analysis after adjustment for patient age

\begin{tabular}{|c|c|c|c|c|}
\hline Natriuretic peptide & Coefficient & $S E$ & Wald $\chi^{2}$ & $P$ \\
\hline $\begin{array}{l}\ln \text { ANF } \\
\ln \text { N-ANF } \\
\ln \text { BNP }\end{array}$ & $\begin{array}{l}\text { ats with LVEI } \\
-1.304 \\
-1.231 \\
-2.532\end{array}$ & $\begin{array}{c}15 \% \text { and } \\
0.509 \\
0.603 \\
0.564\end{array}$ & $\begin{array}{c}15 \mathrm{~mm} \\
6 \cdot 57 \\
4 \cdot 17 \\
20 \cdot 12\end{array}$ & $\begin{aligned} &=17) \\
& 0.010 \\
& 0.041 \\
&<0.001\end{aligned}$ \\
\hline $\begin{array}{l}\ln \text { ANF } \\
\ln \text { N-ANF } \\
\ln \text { BNP }\end{array}$ & $\begin{array}{l}\text { Patients u } \\
-1.259 \\
-1.078 \\
-1.541\end{array}$ & $\begin{array}{l}V E D P \\
0.253 \\
0.311 \\
0.294\end{array}$ & $\begin{array}{c}\mathrm{Hg}(n=1 \\
24 \cdot 70 \\
11 \cdot 98 \\
27 \cdot 41\end{array}$ & $\begin{array}{l}<0.001 \\
<0.001 \\
<0.001\end{array}$ \\
\hline $\begin{array}{l}\ln \text { ANF } \\
\ln \text { N-ANF } \\
\ln \text { BNP }\end{array}$ & $\begin{array}{l}\text { Patie } \\
-0.975 \\
-1.011 \\
-1.964\end{array}$ & $\begin{array}{c}\text { ith } L V E F \\
0.438 \\
0.542 \\
0.476\end{array}$ & $\begin{array}{c}(n=21) \\
4 \cdot 96 \\
3 \cdot 48 \\
17 \cdot 01\end{array}$ & $\begin{array}{r}0.026 \\
0.062 \\
<0.001\end{array}$ \\
\hline $\begin{array}{l}\ln \text { ANF } \\
\ln \text { N-ANF } \\
\ln \text { BNP }\end{array}$ & $\begin{array}{l}\text { Patients with } \\
\text { and no angic } \\
1.029 \\
1.237 \\
2.761\end{array}$ & $\begin{array}{l}D P<15 \\
\text { iic sign of } \\
0.250 \\
0.334 \\
0.413\end{array}$ & $\begin{array}{c}\text { LVEF } \geqslant \\
\text { kinesis }(n \\
16.97 \\
6.30 \\
44.61\end{array}$ & $\begin{array}{r}<0.001 \\
0.012 \\
<0.001\end{array}$ \\
\hline
\end{tabular}

ANF, atrial natriuretic factor; BNP, brain natriuretic peptide; N-ANF, N-terminal pro-atrial natriuretic factor; LVEDP, left ventricular end diastolic pressure; LVEF, left ventricular ejec-
tion fraction.
The ROC plots shown in fig 2 illustrate the sensitivity and specificity of atrial natriuretic factor, $\mathrm{N}$-terminal pro-atrial natriuretic factor, and brain natriuretic peptide measurements with regard to the correct identification of patients with combined raised left ventricular end diastolic pressure and reduced left ventricular ejection fraction throughout the range of peptide concentrations. Table 5 presents the area under the ROC functions for the identification of the previously defined patient subgroups; this provides an index of overall diagnostic accuracy for the cardiac natriuretic peptides. The diagnostic accuracy of brain natriuretic peptide was greater than those of $\mathrm{N}$-terminal pro-atrial natriuretic factor and atrial natriuretic factor for all predefined patient subgroups. According to the ROC area estimation, a randomly selected individual from the subgroup with end diastolic pressure $\geqslant 15 \mathrm{~mm} \mathrm{Hg}$ and ejection fraction $\leqslant 45 \%$ will have a higher plasma brain natriuretic peptide value than a randomly selected individual from the remaining group of patients $79 \%$ of the time, but a higher N-terminal proatrial natriuretic factor value only $61 \%$ of the time.

\section{Discussion}

Important lessons can be learned from the present investigation. First, although plasma concentrations of the cardiac natriuretic peptides show significant associations with indices of left ventricular function, their ability to discriminate between normal and impaired ventricular function, as documented by ROC analyses, is relatively modest. Secondly, plasma brain natriuretic peptide seems to be a better indicator of left ventricular function, and in particular of left ventricular ejection fraction, than atrial natriuretic factor and N-terminal pro-atrial natriuretic factor. Nevertheless, the ability of brain natriuretic peptide determination to discriminate between patients with normal and those with abnormal left ventricular ejection fraction is not very impressive in this series of patients, even after adjustment for patient age. Given the relatively poor diagnostic accuracy of the cardiac natriuretic peptides as indicators of increased left ventricular filling pressures and systolic performance, the clinical usefulness of such
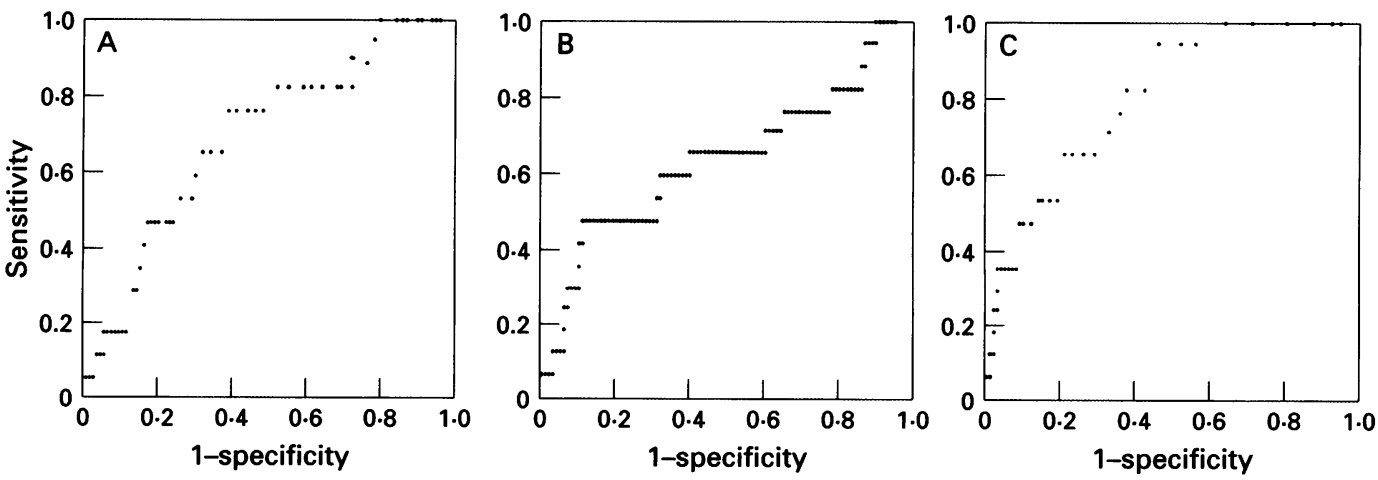

Figure 2 ROC plot of $(A)$ atrial natriuretic factor, (B) $N$-terminal pro-atrial natriuretic factor, and (C) brain natriuretic peptide for distinguishing between patients with left ventricular dysfunction (subjects with left ventricular ejection fraction $\leqslant 45 \%$ and left ventricular end diastolic pressure $\geqslant 15 \mathrm{~mm} \mathrm{Hg}$ ) and the remaining group of patients. 
Table 5 Diagnostic accuracy of the cardiac natriuretic peptides as evaluated by area under the ROC curve estimates

\begin{tabular}{|c|c|}
\hline Natriuretic peptide & Area \\
\hline $\begin{array}{l}\quad \text { Patients with } L \\
\text { ANF } \\
\text { N-ANF } \\
\text { BNP }\end{array}$ & $\begin{array}{l}6 \text { and } L V E D P \geqslant 15 \mathrm{~mm} \mathrm{Hg} \\
0.665 \\
0.610 \\
0.789\end{array}$ \\
\hline $\begin{array}{l}\text { ANF } \\
\text { N-ANF } \\
\text { BNP }\end{array}$ & $\begin{array}{l}E D P \geqslant 15 \mathrm{~mm} \mathrm{Hg} \\
0.680 \\
0.619 \\
0.698\end{array}$ \\
\hline $\begin{array}{l}\text { ANF } \\
\text { N-ANF } \\
\text { BNP }\end{array}$ & $\begin{array}{l}L V E F<45 \% \\
0.625 \\
0.595 \\
0.738\end{array}$ \\
\hline \multicolumn{2}{|c|}{$\begin{array}{l}\text { Patients with } L V E D P<15 \mathrm{~mm} \mathrm{Hg}, L V E F>55 \%, \\
\text { and no angiographic sign of } L V \text { hypokinesis }(n=81)\end{array}$} \\
\hline $\begin{array}{l}\text { ANF } \\
\text { N-ANF } \\
\text { BNP }\end{array}$ & $\begin{array}{l}0.651 \\
0.606 \\
0.761\end{array}$ \\
\hline
\end{tabular}

ANF, atrial natriuretic factor; BNP, brain natriuretic peptide; N-ANF, N-terminal pro-atrial natriuretic factor; LVEDP, left ventricular end diastolic pressure; LVEF, left ventricular ejection fraction.

measurements as a screening measure in the diagnosis of mild cardiac dysfunction seems to be limited.

The modest association observed between cardiac natriuretic peptide concentrations and haemodynamic indices does not accord with the results of several previous small-scale studies of a limited number of patients with a wide range of cardiac function and peptide concentrations. ${ }^{12-141617}$ These studies, however, were not designed to evaluate the diagnostic accuracy of the cardiac natriuretic peptides in the identification of patients with asymptomatic or mildly symptomatic ventricular dysfunction. In a population-based study, plasma concentrations of atrial natriuretic factor correlated weakly with non-invasive indices of heart failure, the association being entirely due to increased concentrations in subjects with severe dyspnoea. ${ }^{28}$ Another study, which did not assess cardiac function objectively, found increased plasma concentrations of atrial natriuretic factor and $\mathrm{N}$-terminal pro-atrial natriueretic factor in subjects with congestive heart failure and ischaemic heart disease, but did not report any data on diagnostic accuracy. ${ }^{29}$ To our knowledge, the only previous large-scale investigation which has attempted to assess the sensitivity and specificity of atrial peptides as indicators of cardiac function is the study by Lerman et al, encompassing an unselected population of patients referred to the Mayo Clinic for radionuclide ventriculography. ${ }^{10}$ The impressive results of the study showed that $\mathrm{N}$-terminal pro-atrial natriuretic factor identified patients with asymptomatic left ventricular dysfunction with a sensitivity and specificity $>90 \%$. The main reason for the discrepancy between the results of Lerman et $a l$ and the present data seems to be related to the low plasma N-terminal pro-atrial natriuretic factor values (28 (13) pmol/1) observed in their control group of 25 subjects. Our laboratory's reference values for N-terminal proatrial natriuretic factor obtained from a sample of 386 presumably healthy men show a much wider distribution (384 (179) $\mathrm{pmol} / \mathrm{l})$ than that of the control group in Lerman et als study. The normal values for $\mathrm{N}$-terminal proatrial natriuretic factor reported by Hall et al (588 (231) pmol/1) in a group of 134 healthy individuals with an average age of 60 (6) years also show a distribution pattern similar to the reference values of our laboratory..$^{30}$ Although reference values may vary considerably among laboratories, the wide scatter of values in healthy individuals and in patients with normal left ventricular function investigated in this study strongly indicates that a pronounced diversity in plasma concentrations is a physiological phenomenon characteristic of the cardiac natriuretic peptides. Our results suggest that a high proportion of false positive classifications-that is, subjects with raised circulating concentrations despite normal cardiac function-is a major limitation in the use of cardiac natriuretic peptides as indicators of mild left ventricular impairment. In addition, many patients with impaired left ventricular function seem to have relatively low circulating concentrations, further contributing to the overlap between patients with reduced and normal ventricular function.

Rather than calculating the sensitivity and specificity at an upper reference value, the present study assessed the overall diagnostic accuracy by estimating the area under the ROC function. Whereas reporting only one specific value for sensitivity and specificity provides a possibly misleading oversimplification of diagnostic accuracy, ROC analysis provides a comprehensive reflection of the ability of the test to make the diagnostic distinction throughout the range of decision thresholds. ${ }^{27}$ To our knowledge, no previous study has evaluated the diagnostic accuracy of cardiac natriuretic peptides for the detection of mild left ventricular impairment by ROC analysis. Blood for cardiac natriuretic peptide measurements was sampled from aorta in the present study. It has previously been convincingly demonstrated that peripheral venous and left ventricular concentrations of atrial natriuretic factor and brain natriuretic peptide correlate closely $\left(r=0.94\right.$ and $r=0.99$, respectively). ${ }^{17}$ Consequently, it is unlikely that our results would have differed had the blood samples been obtained from a peripheral vein.

The relatively poor diagnostic accuracy of circulating cardiac natriuretic peptides does not necessarily imply that measurements of these peptides are unsuitable as criteria for therapeutic intervention. The ability of neurohumoral markers to predict outcome ${ }^{30-34}$ may be more important than their ability to correlate with other surrogates for outcome. Future use of cardiac natriuretic peptide measurement as a criterion for treatment with angiotensin converting enzyme inhibitor should, however, only be considered after its value has been proven in prospective trials in relevant patient populations. We thank Professor Eric Espiner and Dr Tim Yandle, Department of Endocrinology, Christchurch Hospital,
Christchurch, New Zealand for performing the brain natriuretic peptide analyses and Dr Olli Vuolteenaho, Department of Physiology, University of Oulu, Oulu, Finland, for performing the N-terminal pro-atrial natriuretic factor 
analyses. Dr James M DeLeo, Division of Computer Research and Technology, National Institutes of Health, Bethesda, Maryland, USA, generously provided the software programme ROCLAB. We also thank Dr Tor Melberg and Dr Ståle Barvik for performing the physical examinations of the patients and for their contribution in the catheterisation laboratory.

1 Pfeffer MA, Braunwald E, Moyé LA, Basta L, Brown EJ, Cuddy TE, et al. Effect of captopril on mortality and morbidity in patients with left ventricular dysfunction after myocardial infarction. $N$ Engl $\mathcal{F}$ Med 1992;327: 669-77.

2 The Acute Infarction Ramipril Efficacy (AIRE) Study Investigators. Effect of ramipril on mortality and morbidity of survivors of acute myocardial infarction with clinical evidence of heart failure. Lancet 1993;342:821-8.

3 The SOLVD investigators. Effect of enalapril on survival in patients with reduced left ventricular ejection fractions and congestive heart failure. $N$ Engl $f$ Med 1991;325: 293-302.

4 The SOLVD investigators. Effect of enalapril on mortality and the development of heart failure in asymptomatic patients with reduced left ventricular ejection fractions. $N$ patients with reduced left ventric

5 McDonagh T, Morrison C, McMurray J, Duncan D, Ford I, Tunstall-Pedoe H, et al. The prevalence of left ventricI, Tunstall-Pedoe $\mathrm{H}$, et al. The prevalence of left ventricular dysfunctio

6 Remes J, Miettinen H, Reuanen A, Pyörälä K. Validity of clinical diagnosis of heart failure in primary health care. Eur Heart f 1991;12:315-21.

7 Francis GS, Benedict C, Johnstone DE, Kirlin PC, Nicklas $\mathrm{J}$, Liang $\mathrm{C}$, et al. Comparison of neuroendocrine activation in patients with left ventricular dysfunction with and without congestive heart failure: a substudy of the
Studies of Left Ventricular Dysunction (SOLVD). Circulation 1990;82:1724-9.

8 Rouleau JL, deChamplain J, Klein M, Bichet D, Moyé LA, Packer $M$, et al. Activation of neurohumoral systems in postinfarction left ventricular dysfunction. $\mathcal{F} \mathrm{Am} \mathrm{Coll}$ Cardiol 1993;22:390-8.

9 Benedict CR, Johnstone DE, Weiner DH, Bourassa MG, Bittner V, Kay R, et al. Relation of neurohumoral activation to clinical variables and degree of ventricular dysfunction: a report from the Registry of Studies of Left Ventricular Dysfunction. I Am Coll Cardiol 1994;23: 1410-20.

10 Lerman A, Gibbons RJ, Rodeheffer RJ, Bailey KR, McKinley LJ, Heublein DM, et al. Circulating N-terminal atrial natriuretic peptide as a marker for symptomless left-ventricular dysfunction. Lancet 1993;341:1105-9.

11 Wei CH, Heublein DM, Perella MA, Lerman A, Rodeheffer RJ, McGregor CGA, et al. Natriuretic peptide system in human heart failure. Circulation 1993; tide system

12 Motwani JG, McAlpine H, Kennedy N, Struthers AD. Plasma brain natriuretic peptide as an indicator for angiotensin-converting enzyme inhibition after myocarangiotensin-converting enzyme inhibition

13 Raine AEG, Erne $P$, Bürgisser E, Müller FB, Bolli $P$, Burkhart $F$, et al. Atrial natriuretic peptide and atrial pressure in patients with congestive heart failure. $N \mathrm{Engl} \mathrm{F}$ Med 1986;315:533-7.

14 Mathisen $P$, Hall C, Simonsen S. Comparative studies of atrial peptides ANF (1-98) and ANF (99-126) as diagnostic markers of atrial distension in patients with cardiac disease. Scand F Clin Lab Invest 1993;53:41-9.

15 Yoshimura M, Yasue H, Okumura K, Ogawa H, Jougasaki $M$, Mukoyama $M$, et al. Different secretion patterns of atrial natriuretic peptide and brain natriuretic peptide in patients with congestive heart failure. Circulation 1993, 87:464-9.

16 Richards AM, Crozier IG, Yandle TG, Espiner EA, Ikram plasma concentrations namic state in cardiac disease. Br Heart $f$ 1993;69:414-7.
17 Haug C, Metzele A, Kochs M, Hombach V, Grünert A. Plasma brain natriuretic peptide and atrial natriuretic peptide concentrations correlate with left ventricular endpeptide concentrations correlate with left ventricul
diastolic pressure. Clin Cardiol 1993;16:553-7.

18 Choy AMJ, Darbar D, Lang CC, Pringle TH, McNeill GP, Kennedy NSJ, et al. Detection of left ventricular dysfunction after acute myocardial infarction: comparison of clinical, echocardiographic, and neurohormonal methods. Br Heart $\mathcal{F} 1994 ; 72: 16-22$.

19 Struthers AD. Ten years of natriuretic peptide research: a new dawn for their diagnostic and therapeutic use? $\mathrm{Br}$ Med f 1994;308:1615-9.

20 Davidson NC, Coutie WJ, Struthers AD. N-terminal proatrial natriuretic peptide and brain natriuretic peptide are stable for up to 6 hours in whole blood in vitro. Circulation 1995;91:1276 (letter).

21 Hall C, Aaberge L, Stokke O. In vitro stability of $\mathrm{N}$-terminal proatrial natriuretic factor in unfrozen samples: an important prerequisite for its use as a biochemical parameter of atrial pressure in clinical routine. Circulation 1995;91:911 (letter).

22 Sandler H, Dodge HT. The use of single plane angiocardiograms for the calculation of left ventricular volume in man. Am Heart $\mathcal{f}$ 1968;75:325-34.

23 Omland T, Bonarjee VVS, Aakvaag A, Aarsland T, Dickstein $\mathrm{K}$. The relationship between early plasma atrial natriuretic factor levels and exercise performance after myocardial infarction. Eur Heart $f$ 1993;14:1022-6.

24 Kettunen RVJ, Leppäluoto J, Jounela A, Vuolteenaho $O$. Plasma N-terminal atrial natriuretic peptide in acute Plasma N-terminal atrial natriuretic peptide in acu

25 Yandle TG, Richards AM, Gilbert A, Fisher S, Holmes S, Espiner EA. Assay of brain natriuretic peptide (BNP) in human plasma: evidence for high molecular weight BNP as a major plasma component in heart failure. $\mathcal{F}$ Clin Endocrinol Metab 1993;76:832-8.

26 DeLeo JM. Receiver operating characteristic laboratory (ROCLAB): software for developing decision strategies that account for uncertainty. Proceedings of the Second International Symposium on Uncertainty Modeling and Analysis. Los Alamitos, California: IEEE Computer Society Press, 1993:318-25.

27 Zweig MH, Campbell G. Receiver-operating characteristic ROC) plots: a fundamental evaluation tool in clinical medicine. Clin Chem 1993;39:561-77.

28 Caidahl K, Hedner J, Hedner T. Atrial natriuretic peptide and catecholamines in peripheral blood as indicators of cardiac dysfunction in the general population. Clin $\mathrm{Sci}_{\mathrm{i}}$ 1988;74:587-94.

29 Wallén T, Landahl S, Hedner T, Hedner J, Hall C. Atrial peptides, ANP (1-98) and ANP (99-126) in health and disease in an elderly population. Eur Heart $\mathcal{f} 1993 ; 14$ : 1508-13.

30 Hall C, Rouleau JL, Moyé LA, de Champlain J, Bichet D, Klein $\mathrm{M}$, et al. N-terminal proatrial natriuretic factor. An independent predictor of long-term prognosis after independent predictor of long-term prognosis

31 Omland T, Aarsland T, Aakvaag A, Lie RT, Dickstein K. Prognostic value of plasma atrial natriuretic factor, norepinephrine and epinephrine in acute myocardial infarction. Am 7 Cardiol 1993;72:255-9.

32 Omland T, Bonarjee VVS, Nilsen DWT, Sundsfiord JA, Lie RT, Thibault G, et al. Prognostic significance of Nterminal pro-atrial natriuretic factor $(1-98)$ in acute myocardial infarction: comparison with atrial natriuretic factor (99-126) and clinical evaluation. Br Heart $\mathcal{f} 1993$; 70:409-14.

33 Rouleau JL, Packer M, Moyé LA, de Champlain J, Bichet $D$, Klein $M$, et al. Prognostic value of neurohumoral activation in patients with an acute myocardial infarction: effect of captopril. $\mathcal{F ~ A m ~ C o l l ~ C a r d i o l ~ 1 9 9 4 ; ~}$ 24:583-91.

34 Arakawa N, Nakamura M, Aoki H, Moriai N, Suzuki T, Hiramori K. Prognostic value of plasma brain natriuretic peptide concentration in patients with acute myocardial infarction (abstract). Circulation 1994;90:I-279. 